\title{
THE STUDENTS’ DIFFICULTIES IN USING DEMONSTRATIVE PRONOUN
}

\author{
Muhammad Arief Paturusi \\ English Education Department, Faculty of Teacher Training and Education \\ Muhammadiyah University of Makassar \\ arifpaturusi@unismuh.ac.id
}

\begin{abstract}
The objective of the research was to find out the Students' Difficulties in Using Demonstrative Pronoun at the second year of SMP Aisyiyah Sungguminasa. The researcher applied descriptive quantitative approach as method for analyzing the data. The researcher collected the data through objective test and questionnaire. Objective test was use to find out the students ability in using demonstrative pronoun. The test formulated with 20 items multiple choice and questionnaire was used to find out the students difficulties in using demonstrative pronoun, the sample of this research was the second year students of SMP Aisyiyah Sungguminasa in academic year 2014/2015, the sample consisted of 26 students which were taken from the population 26 students. The data obtained from the test were firstly tabulated, and then analyzed into technique of percentage and mean analysis. The result of the research data showed that the ability of the second year students of SMP Aisyiyah Sungguminasa found difficult in using Demonstrative Pronoun with the total mean score 41 or classified as fairwith highest score was 60 and the lowest score is 1.6. The finding also showed that among the 26 students, there were $47.25 \%$ the students face difficulties in using Demonstrative pronoun "this" in sentences correctly. While there were $65.38 \%$ the students faced difficulties in using "that". In using demonstrative pronoun "these" there were 93.26\% the most error. And there were $44.61 \%$ the students faced difficulties in using demonstrative pronoun "those". The researcher concluded that almost all of students got the difficulties in using demonstrative pronoun. The difficulties were caused the students had less understanding about demonstrative pronoun because they never learned about it before.
\end{abstract}

Keywords: Students' Difficulties, Demonstrative Pronoun

\section{INTRODUCTION}

English as the one of languages that is taught in many educational institutes (formal and non formal) has many problems in teaching it. One of them is about the methodology of teaching. The problems which come in the teaching process are caused of many factors, especially from the students' interest toward English as their subject. The interest of ones can appear when they are given an interesting thing. That is also happening in English teaching. When the students are given an interesting method which can involve them in learning process, of course, they will be enthusiastic to accept the material. 
Grammar is the study of the structure of the language. In grammar there are several important aspects that must be learned. Such as: vocabulary, translation, and structure. Grammar can help the students maintain to use of formal English, they feel confident when they speak and write it (John, 2003: 18). The students who have sufficient knowledge of grammar can master English easier. They do not find many difficulties in writing and speaking English grammatically. It is so because they can understand the pattern of sentences, less units, and the phenomenon of the language (Scott, 1976: 121). Without some understanding of grammar, students would not be able to do anything more than uttering separate items of language for separate function (Harmer, 1986: 22).

However, there are still many students who find difficulty to learn it. One of the reasons is they do not mastery the grammar. Since many years ago, grammar has been specter for them. In their opinion, grammar is the most difficult thing and almost impossible to understand. Consequently, they are lazy to learn it and eventually they cannot use grammar rules in English.

In this research, the researcher chooses one of them is the structure students who learn English as the second language especially in using demonstrative pronoun in context correctly. The problem appear because of the various kinds and functions of demonstrative pronoun on one hand, and the students knowledge of demonstrative pronoun to make sentences either in speaking or writing on the other hand. In connection with this case, it is important to identify the roles of English demonstrative pronoun. Without some understanding of grammar, students would not be able to do anything more than uttering separate items of language for separate function (Harmer, 1986: 22).

This problem is getting more and more distinct when the researcher did preobservation that is done in P2K at SMP PGRI Sungguminasa Kabupaten Gowa, the students face problem in learning Grammar. During the teaching learning process, when the students are given written task, the researcher found that most students in the class cannot write sentences grammatically. For instance, use of demonstrative pronoun. Most students in class VIII do not understand well how to use demonstrative pronoun in sentences or how to putting demonstrative pronoun in sentences. 


\section{CONCEPT OF PRONOUN}

\section{What is pronoun?}

Langan (2003: 197) states that pronouns are words that take the place of noun (words for person, place or things). In fact the word pronoun means for a noun. Pronoun are shortcuts that keep you from unnecessary repeating words in writing. Child (1998) states that pronouns refer to and replace nouns (the names of people, places and things) that have already been mentioned, or that the speaker/ writer assumes are understood by the listener or reader.

\section{The rule to make pronoun}

The three rules bellow will help you to avoid common mistakes people make with pronoun:

a. A pronoun must refer clearly to the word it replaces. A sentence may be confusing and unclear if:

1) A pronoun appears to refer to more than one word, as in this sentence: I locked my suitcase in my car, and then it was stolen. What was stolen? It is unclear whether the suitcase or the car was stolen. It should be: $I$ locked my suitcase in my car, and then my car was stolen

2) The pronoun does not refer to any specific word, look at this sentence: We never buy fresh vegetables at that store because they charge too much. Who charge too much? There is no specific word that they refers to. It should be We never buy fresh vegetables at that store because the owners charge too much.

b. A pronoun must agree in number with the word or words it replaces. If the word of pronoun refers to is singular, the pronoun must be singular. If the word is plural, the pronoun must be plural. Pay attention to this sentences:

Lola agreed to lend me her Billie Holiday album.

The gravediggers sipped coffee during their break.

In the first example, the pronoun her refers to the singular word Lola. In the second example, the pronoun their refers to the plural word gravediggers.

c. Pronoun should not shift unnecessary in point of view. When writing a 
paper, be consistent in your use of first-, second-, or third-person pronouns.

If you start writing in the first-person $I$, do not jump suddenly to the second person you. Or you are writing in the third person they, do not shift unexpectedly to you. Look at the examples:

\section{Inconsistent}

One reason that I like living in the city is that you always have a wide choice of sports events to attend. (The most common mistake people make is to let a you slip into their writing after they start with another pronoun).

\section{Consistent}

One reason that I like living in the city is that I always have a wide choice of sports events to attend

According to Rozakis (2003: 24) states that the meaning of a pronoun comes from its antecedent, the noun or pronoun to which it refers. Your speech and writing will be confusing if your pronoun reference is unclear. Carelessly placed pronouns can create unintentionally funny sentences as well as confusing ones. There are two ways to prevent pronoun confusion.

1) A pronoun must clearly refer to a single antecedent. A common writing and speech problem occurs when the same pronoun refers to more than one antecedent. Remember that a pronoun replaces a noun. To make sure that your writing and speech are clear, always use the noun first before you use the pronoun. Clarify the sentence by replacing the unclear pronouns with nouns. That way, all the remaining pronouns will clearly refer to a single antecedent. Guilt and unkindness can be emotionally destructive to you and your friends. You must get rid of them. The word them can refer to guilt, unkindness, or your friends. Here are two ways you could rewrite this sentence:

2) Guilt and unkindness can be emotionally destructive to you and your friends. You must get rid of these issues or guilt and unkindness can be emotionally destructive to you and your friends. You must get rid of these destructive emotions 
3) Place pronouns close to their antecedents. If too many phrases come between a pronoun and its antecedent, the sentence can be difficult to read and understand. This can happen even if the intervening material is logically related to the rest of the sentence. Consider the following sentence: After meeting a few guests, the President entered the reception.

\section{Demonstrative pronouns}

Frank (1972:21) states that demonstrative pronoun is the same pronouns used for demonstrative adjectives - this, that, these and those. The difference is in the sentence structure.

- The demonstrative pronoun takes the place of the noun phrase.

- The demonstrative adjective is always followed by a noun.

The demonstrative pronouns are this, that, these, and those. Like all pronouns, they replace nouns. Demonstrative pronouns are used to replace specific people or things that have been previously mentioned (or are understood from context).

A demonstrative pronoun tells us whether it is replacing something singular or plural and whether that thing(s) is close by or farther away.

This and That Represent Singular Nouns

This and that replace singular nouns.

This represents something close by. For example:

- This is very smelly.

That represents something farther away. For example:

- You can smell that from here.

These and Those Represent Plural Nouns

These and those replace plural nouns.

These represents something close by. For example:

- These smell rotten.

Those represents something farther away. For example:

- Do not paint those 
The family of demonstratives (this/ that/ these/ those/ such) can behave either as pronouns or as determiners.

As pronouns, they identify or point to nouns.

- That is incredible! (referring to something you just saw)

- I will never forget this. (referring to a recent experience)

- Such is my belief. (referring to an explanation just made)

As determiners, the demonstratives adjectivally modify a noun that follows. A sense of relative distance (in time and space) can be conveyed through the choice of these pronouns/determiners:

- These [pancakes sitting here now on my plate] are delicious.

- Those [pancakes that I had yesterday morning] are even better.

- This [book in my hand] is well written;

- that [book that I'm pointing to, over there, on the table] is trash.

A sense of emotional distance or even disdain can be conveyed with the demonstrative pronouns:

- You're going to wear these?

- This is the best you can do?

Pronouns used in this way would receive special stress in a spoken sentence. When used as subjects, the demonstratives, in either singular or plural form, can be used to refer to objects as well as persons.

- This is my father.

- That is my book.

In other roles, however, the reference of demonstratives is non-personal. In other words, when referring to students, say, we could write "Those are loitering near the entrance during the fire drill" (as long as it is perfectly clear in context what "those" refers to). But we would not write "The principal suspended those for two days"; instead, we would have to use "those" as a determiner and write "The principal suspended those students for two days."(Frank, 1972:22) 


\section{RESEARCH METHODOLOGY}

This research applied descriptive research. It aimed to describe the student's difficulties in using demonstrative pronoun. The variable of this research was the students' difficulties in using demonstrative pronoun at the second year of SMP Aisyiah Sungguminasa in 2015/2016 academic year. The indicator of this research was demonstrative pronoun especially this, that, these, and those.

The population of this research was the second year students of SMP Aisyiah Sungguminasain 2015/2016 academic year. There was one class and consisted of 26 students, so the total number of population was 26 students. The sample used in this research is total sampling technique. The researcher decided all the students of the second year, so the total number of sample in this research is 26 students.

To accelerate this research process, the researcher used objective test in collecting data. Multiple choice and questionnaire aim to find out the students' difficulties in using demonstrative pronoun at the second year students of SMP Aisyiah Sungguminasa

In collecting the data, the researcher followed the following procedures:

1. The researcher distributed test.

2. The researcher explained how to work the test.

3. The students got sixty minutes to complete test.

4. The researcher collected the students' answer.

The researcher also gave questionnaire to the students to responds to a series of statements by indicating whether one Strongly Agree (SA), Agree (A), Undecided (UN), Disagree (D), or Strongly Disagree (SD) with each statement. Each response in associated with a point value and individual's score which is determined by summing with a point value of each statements. The point value was assigned to response the positive statements and negative statements. 
Table 1. Likert Scale

\begin{tabular}{|c|c|c|c|c|c|}
\hline Items & SA & A & UN & D & SD \\
\hline Positive statements & 5 & 4 & 3 & 2 & 1 \\
\hline Negative statements & 1 & 2 & 3 & 4 & 5 \\
\hline
\end{tabular}

Source : (Azwar : 1995: 140)

\section{FINDINGS AND DISCUSSION}

\section{A. Findings}

The finding of the research presented with the analysis of the test while the discussion section concerned with interpretation and explanation of the finding. To find out the ability of the students in test, the raw score of the students were tabulated. After tabulating the raw score, the researcher determined the score of each students and its classification.

\section{The students' difficulties in using demonstrative pronoun}

Based on the interview, some of students' answering about 'their understanding in using demonstrative pronoun', the researcher concluded that:

1) Almost all of students got the difficulties in using demonstrative pronoun.

2) The difficulties were caused the students had less understanding about demonstrative pronoun because they never learned about it before.

3) The students also got the difficulties in using demonstrative pronoun that be applied in sentence.

4) The students got the difficulties to distinguish the using of types of demonstrative pronoun because of the students' first language.

It was proven when the researcher asked them to make a sentence by using demonstrative pronoun. Almost all of students only knew the meaning of 'this' and 'that', but they didn't know about 'these' and 'those'.

The following students' statement about the difficulties in using demonstrative pronoun: 
1) Fadly said "iye sulit, karena masih belum ku mengerti apa itu demonstrative pronoun (yes, I did. Because I still don't understand about demonstrative pronoun"

2) Andini said "iya pak sulit, belum pernah ki diajarkan sama ibu itu pak, mengaji terus ji kalau masuk, jarang ki belajar bahasa inggris (yes,I did. We were never taught by our teacher, because in English learning, the teacher just asked us to recite the holy al-Qur'an. We rare studied English.

3) Bambang said "iye pak, tidak ku tahu pi bedakan itu these sama those. Itu ji saja ku tahu this sama that (yes, I did. I don't know to distinguish the using of these and those. I only know about this and that)"

\section{The Students' Ability in Test.}

The rate percentage by the second year students of SMP Aisyiah Sungguminasa is shown as follows:

Table 1. Rate Percentage of the Students' Ability in Test

\begin{tabular}{|c|c|c|c|c|} 
No & Classification & Score & Frequency & $\begin{array}{c}\text { Percentage } \\
(\%)\end{array}$ \\
\hline & & $90-100$ & 0 & $\mathbf{0}$ \\
1. & Very Good & $70-89$ & 1 & $\mathbf{4}$ \\
$\mathbf{2 .}$ & Good & $50-69$ & 6 & $\mathbf{2 3}$ \\
$\mathbf{3 .}$ & Fair & $30-49$ & 14 & $\mathbf{5 4}$ \\
$\mathbf{4 .}$ & Poor & 5 & $\mathbf{1 9}$ \\
\hline 5. & Very Poor & $10-29$ & $\mathbf{2 6}$ & $\mathbf{1 0 0 \%}$ \\
\hline
\end{tabular}


The data above can also be shown from the graphic below :

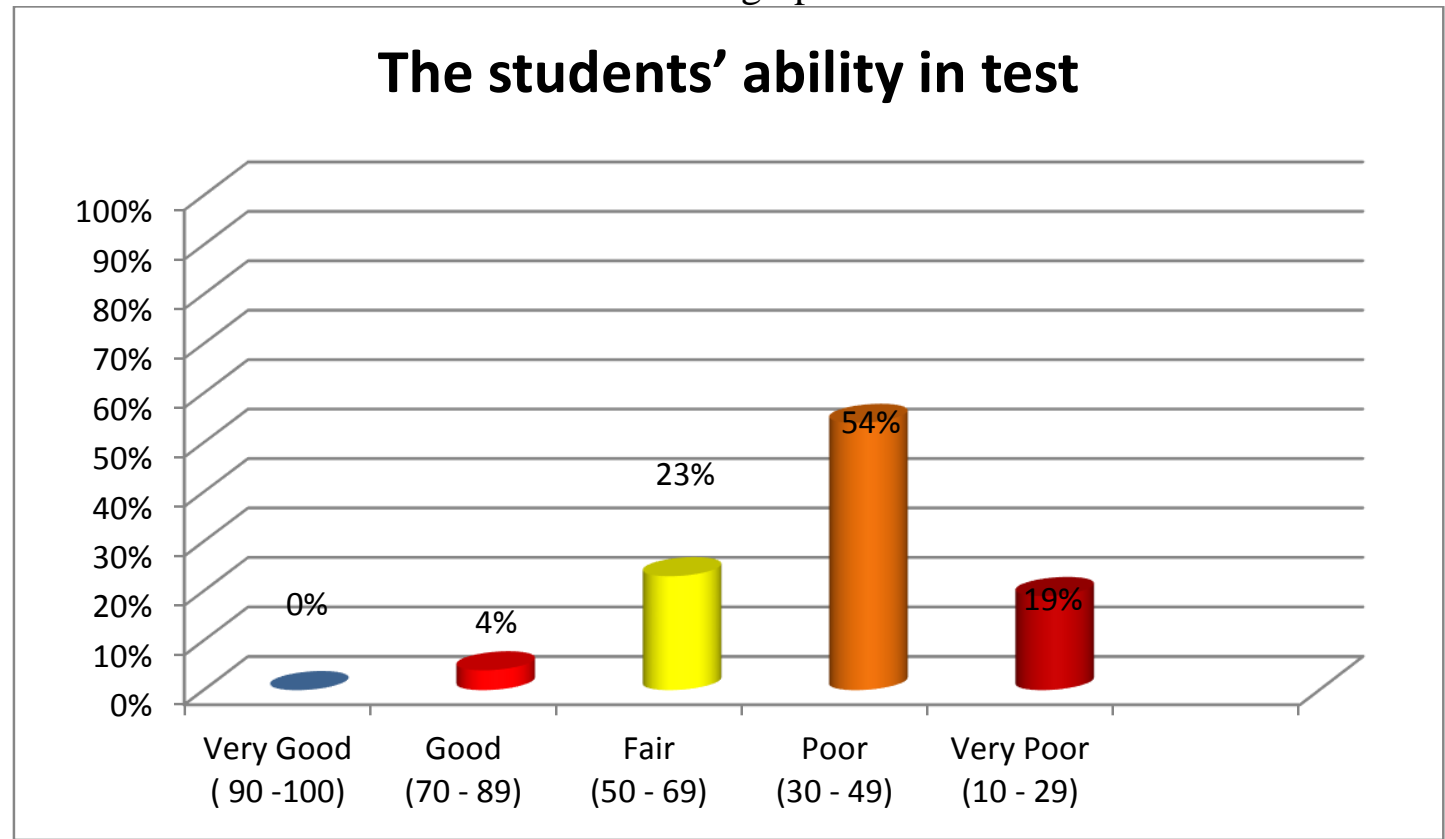

Figure 1: The Percentage of the Students' Ability in Test

Table 1 above, showed that among the 26 students, none of them (0\%) is classified as very good, and just 1 students (4\%) are classified as good. While 6 (23\%) students are classified as fair, 14 (54\%) students are classified as poor and 5 of $(19 \%)$ is classified as very poor. It can be concluded that the ability of the students in test is fair which is shown the total mean score 41 with highest score is 80 and the lowest score is 25 (see appendix C).

The following table is shown the students' mean score in using demonstrative pronoun:

Table 2. The students' mean score in using demonstrative pronoun

\begin{tabular}{|c|c|}
\hline Variable & Mean score \\
\hline This & 13.7 \\
\hline That & 9 \\
\hline These & 1.75 \\
\hline Those & 14.4 \\
\hline
\end{tabular}

The table 2 above was calculated by the sum of score divided the number of subject. It showed that the mean score of using 'this' was 13.7, and there was 9 of the mean score in using 'that'. While the mean score in using 'these' and 'those' were 1.75 and 14.4. 
To have a description about the area of the difficulties faced by the students in using demonstrative pronoun, the researcher presented the table as follows:

Table 3. The Score of the Students in Using Demonstrative pronoun

\begin{tabular}{|c|c|c|c|c|}
\hline No. & $\begin{array}{c}\text { Demonstrative } \\
\text { pronoun }\end{array}$ & Frequency & Correct answer & Incorrect Answer \\
\hline & & & & 86 \\
1. & This & 7 & 36 & 68 \\
2. & That & 4 & 7 & 97 \\
3. & These & 5 & 72 & 58 \\
4. & Those & 4 & \\
\hline
\end{tabular}

The table 3 above showed that there were 96 items correct answer. It means that 86 items test the students made errors or incorrect answer from 182 items test in using Demonstrative pronoun "this". While in using demonstrative pronoun "that" there were 36 items test correct answer. It means that there were 68 items test the students made errors, and in using Demonstrative pronoun "these" there were 7 items test correct answer and 97 items test the students made errors or faced difficulties (See appendix D). Otherwise in using demonstrative pronoun "those", there were 72 items correct answer and 58 items incorrect answer.

The frequency, and the percentage of difficulties in using Demonstrative pronoun. The data presented as follow:

Table 4. Rate Percentage of the Students' Errors in demonstrative pronoun

\begin{tabular}{|c|c|c|c|}
\hline No. & $\begin{array}{c}\text { Demonstrative } \\
\text { pronoun }\end{array}$ & Frequency & $\begin{array}{c}\text { Percentage } \\
(\mathbf{\%})\end{array}$ \\
\hline 1. & This & 86 & 47.25 \\
2. & That & 68 & 65.38 \\
3. & These & 97 & 93.26 \\
4. & those & 58 & 44.61 \\
\hline
\end{tabular}


The data above can also be shown from the graphic below :

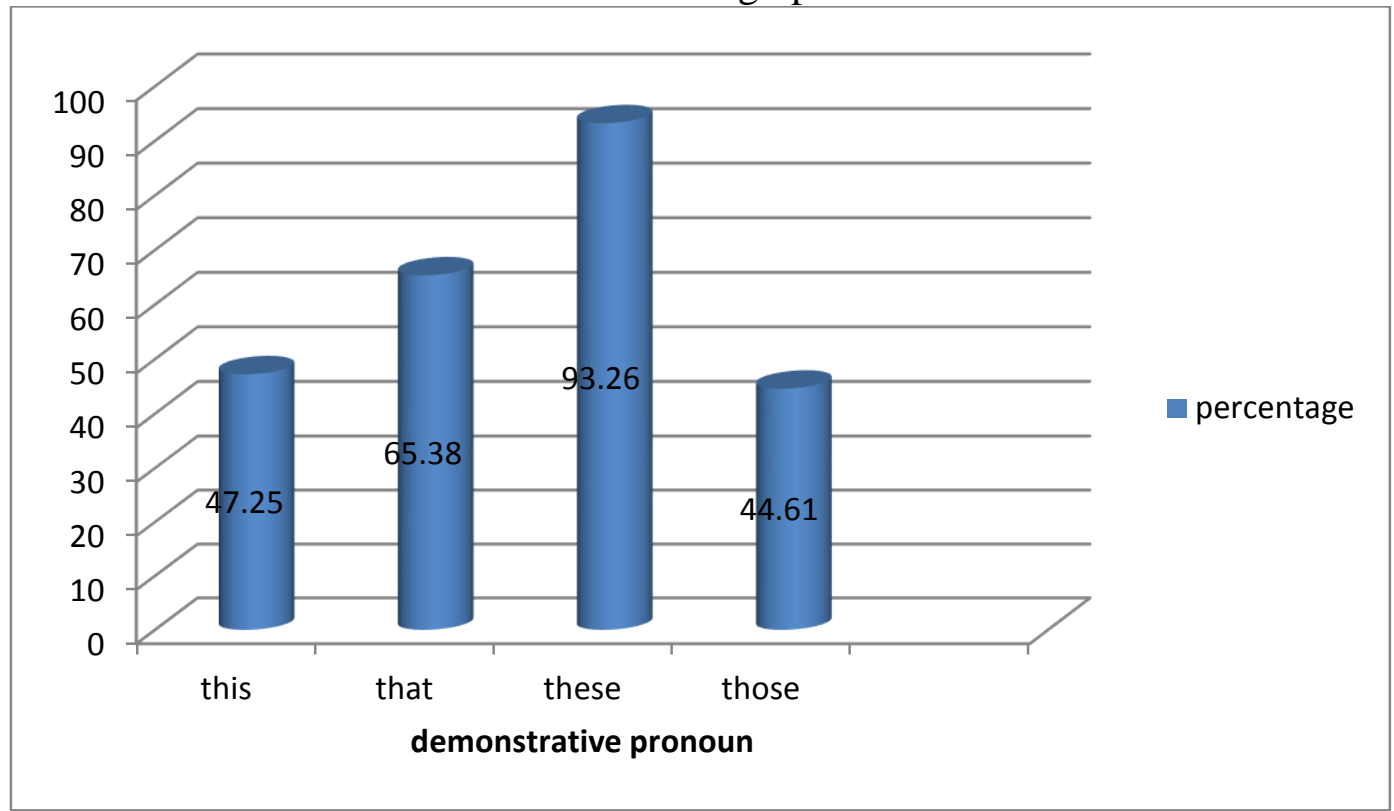

Figure 2: The Percentage of the Students' Errors in Using Demonstrative Pronoun

The table 4 above showed that there were $47.25 \%$ the students face difficulties in using Demonstrative pronoun "this" in sentences correctly. While there were $65.38 \%$ the students faced difficulties in using "that". In using demonstrative pronoun "these" there were $93.26 \%$ the most error. And there were $44.61 \%$ the students faced difficulties in using demonstrative pronoun "those". The data above also showed that demonstrative pronoun "these" most mistaken that students did.

\section{Questionnaire Test}

Based on the data analysis, it was found that the total scores of each of the response categories are shown in the table 5 as follows :

Table 5. The Total Scores

\begin{tabular}{|c|cc|}
\hline Response Categories & Positive Statement & Negative Statement \\
Strongly Agree & 60 & 8 \\
Agree & 23 & 17 \\
Undecided & 26 & 30 \\
Disagree & 13 & 39 \\
Strongly Disagree & 8 & 36 \\
\hline
\end{tabular}

The table 5 above showed that 60 scores strongly Agree, 23scores Agree, 26 scores undecided, 13 scores Disagree and 8 scores Strongly Disagree in positive statement. Besides, in negative statement showed that 8 scores Strongly 
Agree, 17 scores Agree, 30 scores Undecided, 39 scores Disagree and 36 scores Strongly Disagree. (See appendix)

Besides, from the total scores stated above, it was found that the mean scores of each of the response categories are shown in the table 6 as follows:

Table 6. The Mean Scores

\begin{tabular}{|c|cc|} 
Response Categories & Positive Statement & Negative Statement \\
\hline Strongly Agree & 60 & 1.6 \\
Agree & 18.4 & 6.8 \\
Undecided & 15.6 & 18 \\
Disagree & 5.2 & 31.2 \\
Strongly Disagree & 1.6 & 36 \\
\hline
\end{tabular}

(for detail, see appendix )

Finally, the percentage of response for each of the response categories are found like in the table 7 as follows :

Table 7. The Percentage of the Responses

\begin{tabular}{|c|cc|}
\hline Response Categories & Positive Statement & Negative Statement \\
Strongly Agree & 59.5 & 1.7 \\
Agree & 18.2 & 7.3 \\
Undecided & 15.5 & 19.2 \\
Disagree & 5.2 & 33.3 \\
Strongly Disagree & 1.6 & 38.5 \\
\hline T o t a l & $100 \%$ & $100 \%$ \\
\hline
\end{tabular}

The data above can also be shown from the graphic below :

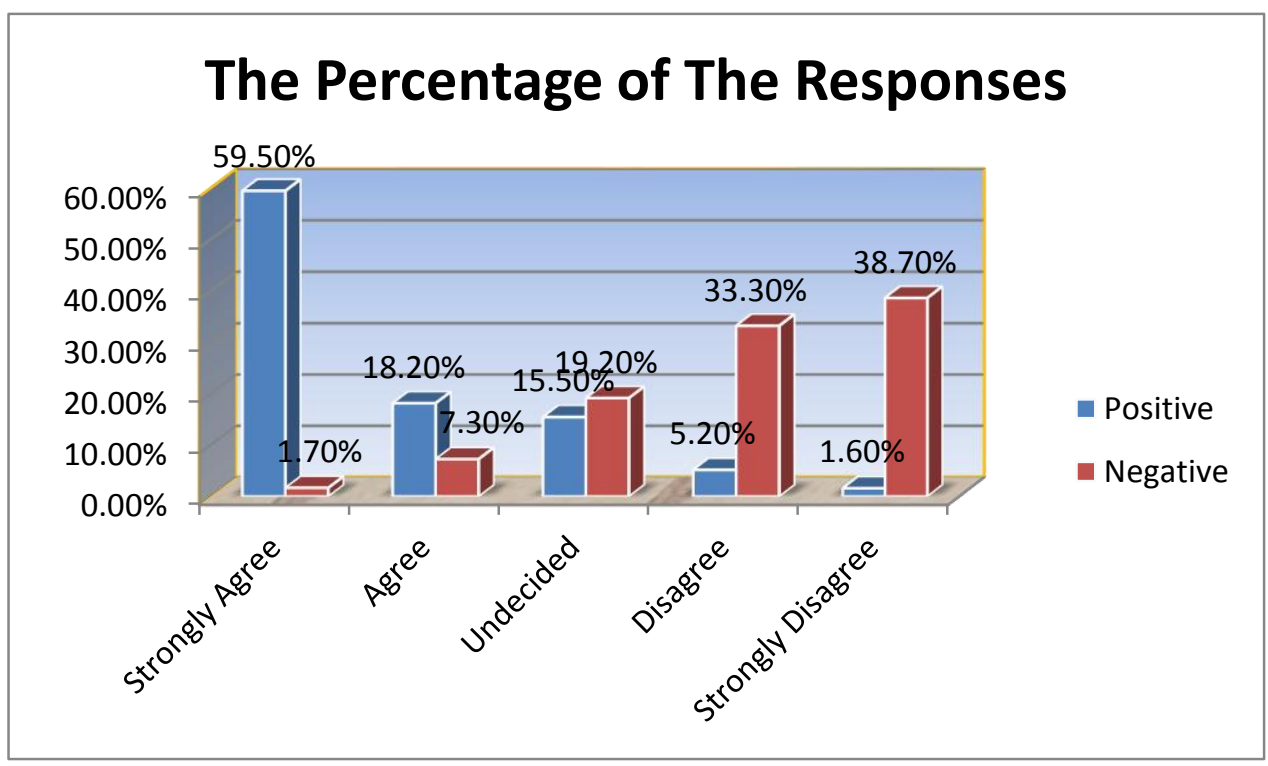

Figure 5: The Percentage of the Responses Questionnaire 
The table 7 above showed that there were 59.5\% students chose Strongly Agree from 504 items in positive statement and 18.2\% Agree, 15.5\% Undecided, 5.2\%Disagree, and then $1.6 \%$ students chose Strongly Agree. While $1.7 \%$ students chose Strongly Agree from 468 items in negative statement and 7.3\% Agree, 19.2\% Undecided, 33.3\% Disagree, and then $38.7 \%$ students chose Strongly Agree. The researcher concluded that the students faced difficulties in using demonstrative pronoun (this, that, these, those) in response categories because in negative statement there were students chose undecided, disagree and strongly disagree, it is meant that they got difficulties in using demonstrative pronoun.

\section{B. DISCUSSIONS}

\section{The students' difficulties in using demonstrative pronoun}

In this research, the researcher used interview questions to reinforce the collecting data. For this collecting data, the researcher only chose 15 students to be interviewed. Based on the students' answer, there were 12 students that got the difficulties in learning demonstrative pronoun. As following statements from some students' answering:

Almost all of students agreed that English is important to learn in the school. They were Magfirah, Musdalifah, Bambang, Firnanda, and some of the other students. Like Firnanda's answering that:

"Penting! Alasannya karena ingin meluaskan wawasan (It's important because I want to expand my knowledge)"

Generally, some of students almost had the same answer for the reason why English is important to learn in the school. For an example: Mufly, Rudianto, Samsuriana, and the other students. They said that:

"Karena bahasa inggris adalah bahasa dunia (Because English is international language)"

All of students answered that they never learnt about demonstrative pronoun before and didn't know about it. As an example Rian and Jumriati had the similar answer, they said that: 
Rian said "belumpi! Tidak pernah ki diajarkan sama guru (not, yet! We were never taught by the teacher)."

Jumriati said "tidak ku tahu apa itu demonstrative pronoun karena tidak pernah ki di ajarkan (I don't know because we never learnt about it)"

In this case, the researcher would explain about demonstrative pronoun after he heard about the students' answering that they were never learned about demonstrative pronoun. It did to make the students had understanding about demonstrative pronoun. After did it, the researcher was able to measure students' difficulties in using demonstrative pronoun.

All of students understood the meaning of demonstrative pronoun after the researcher explained about it. They had similar answer for the question that what demonstrative is.

"Demonstrative pronoun itu kata petunjuk (demonstrative pronoun is word clues)"

For the question what types of demonstrative pronoun, there were only four students that had correct answer, seven students almost had the correct answer, and four students really didn't know the types of demonstrative pronoun.

According to four students (Rian, Rena, Herlinda, and Putri) that had correct answer, they said that:

"This, that, those, and these"

According to seven students that almost had the correct answer, generally they just mentioned some of demonstrative pronoun. Like Magfirah, Musdalifa, Rudianto, Jumriati, Syamsuryana, they just mentioned two of them.

"Dua ji jenisnya mungkin, that ji sama this (I think only this and that)"

And Mufly mentioned three of them.

"This, those, sama that (this, those, and that)"

Almost of the students answered that they weren't able when the teacher asked for them to make a sentence by using demonstrative pronoun. And only one student was able to make the sentence. The generally answer the students said that:

“tidak ku tau ki, pak (I don't know, sir)" 
"Pake bahasa Indonesia ji, pak..contohnya: ini buku saya (just using Indonesia, sir, for example: this is my book) '"

And just Rian got the correct answer.

"contohnya itu, this pen is mine (for example: this pen is mine)"

Refer to the questions that asked the students what the differences among the using of demonstrative pronoun, almost all of the students could only answered about this and that, "this" is to appoint the close object, and "that" is to appoint the distance object. For example in the statements as follow:

Herlinda said "kalau this bendanya dekat, kalau that jauhki ('This' is for close object, and 'that' is for distance object)'.

Rena said "kalau this bisa dipegang bendanya, kalau that tidak (The object of 'this' can be touched, and 'that' can't be).

Almost all of students didn't know when the types of demonstrative pronoun (this, that, these, and those) were used. They just answered with the same answering of the question "what the differences among the using of demonstrative pronoun'.

Almost all of students felt that they got the difficulties in using demonstrative pronoun. They felt hard to learn about that, because they never learned about it before. For example in the statements as follow:

Fadly said "iye sulit, karena masih belum ku mengerti apa itu demonstrative pronoun (yes, I did. Because I still don't understand about demonstrative pronoun"

Andini said "iya pak, belum pernah ki diajarkan sama ibu itu pak, mengaji terus ji kalau masuk, jarang ki belajar bahasa inggris (yes, I did. We were never taught by our teacher, because in English learning, the teacher just asked us to recite the holy al-Qur'an. We rare studied English.

Bambang said "iye pak, tidak ku tahu pi bedakan itu these sama those. Itu ji saja ku tahu this sama that (yes, I did. I don't know to distinguish the using of these and those. I only know about this and that)"

The discussion aims to describing the students' ability in test. Based on some of students' answering about 'their understanding in using demonstrative pronoun'. The researcher concluded that almost all of students got the difficulties 
in using demonstrative pronoun. The difficulties were caused the students had less understanding about demonstrative pronoun because they never learned about it before. The students also got the difficulties in using demonstrative pronoun that be applied in sentence. It was proven when the researcher asked them to make a sentence by using demonstrative pronoun. Almost all of students only knew the meaning of 'this' and 'that', but they didn't know about 'these' and 'those'. According to harmer $(1986 ; 22)$ states that without some understanding of grammar, students would not be able to do anything more than uttering separate items of language for separate function.

\section{Objective test}

Based on the result of data analysis of the test, the researcher found that the ability of the students in test is fair. It is proved by the total mean score of the students 41 with the highest score is 60 and the lowest score is 1.6. Most of the Second Year Students of SMP Aisyiah Sungguminasa made errors in using Demonstrative pronoun and the types of Demonstrative pronoun that are most frequently used incorrectly by the students is "these" that indicate with the total number of errors made by the students are 90 items test from 104 items test.

A description about the area of the difficulties faced by the students in using demonstrative pronoun, the researcher concluded that there were 96 items correct answer. It means that 86 items test the students made errors or incorrect answer from 182 items test in using Demonstrative pronoun "this". While in using demonstrative pronoun "that" there were 36 items test correct answer. It means that there were 68 items test the students made errors, and in using Demonstrative pronoun "these" there were 7 items test correct answer and 97 items test the students made errors or faced difficulties (See appendix). Otherwise in using demonstrative pronoun "those", there were 72 items correct answer and 58 items incorrect answer.

There were $47.25 \%$ the students face difficulties in using Demonstrative pronoun "this" in sentences correctly. While there were $65.38 \%$ the students faced difficulties in using "that". In using demonstrative pronoun "these" there were 
93.26\% the most error. And there were $44.61 \%$ the students faced difficulties in using demonstrative pronoun "those".

The data above also showed that demonstrative pronoun "these" most mistaken that students did. Some of students sometimes didn't understand the meaning or the using of demonstrative pronoun. According to Resmiawati (1999) concluded the students of SLTPN I Parangloe Gowa faced difficulties in using Demonstrative Pronoun. We need one technique that can help the students that is by using picture game.

\section{Questionnaire}

The discussion about the difficulties faced in using Demonstrative pronounand it can be analyzed from the rusult of the questionnaire. From the results of this research, the researcher concludes that many students failed in using Demonstrative pronoun because they faced many difficulties.

\section{CONCLUSION}

Based on the research findings and discussion in the previous chapter, the researcher concluded that the Second Year Students of SMP Aisyiah Sugguminasa found it difficult in using Demonstrative pronoun (this, that, these and those). It was proved by the total mean score 41 or classified as fair. According the finding of analysis demonstrative pronoun which express "these" is the most difficult. Based on the result of questionnaire given, some aspects made the students difficult in using Demonstrative pronoun (this, that, these, and those) in the sentences. Beside that, after explain about demonstrative pronoun (this, that, these, those) the students answer of objective test and filled the questionnaire. The data of questionnaire shows that $65.38 \%$ students feel easy in using demonstrative pronoun and help them to understand the material. Then $3.58 \%$ students have difficulties in using demonstrative pronoun in this test.

\section{BIBLIOGRAPHY}

Allen, Stannard. 1995. Living English Structure. London: Longman Inc.

Childs, Leslie. 1998. Part of Speech. Canada: National Literacy Secretariat of Human Resource Development.

Conlin and Herman. 1967. Grammar Form. Makassar: CV. Berkah Berani. 
Dalle, Basri. 2010. Fudamental of Research Methodology. Makassar: Unpublished.

Descriptive Research. http://www.okstate.edu/ag/.htm (accessed on 18 july, 2014)

Frank, Marcella. 1972. Modern English: A Practical Reference Guide. New Jersey: Prentice Hall Inc.

Gatenby and Wakefiled. 1960. Grammar Use. London: Charles E. Merill Publishing Company.

Gay, L. R. 1981. Educational Research. New York: Charles E. Merrill publishing Company.

1987. Educational Research Competencies for Analysis and Application Columbus: Merrill Publishing Company.

Harahap, Aloan. 1970. Practical English. Semarang.

Hariyono, Rudy. 2002. Complete English Grammar. Surabaya: Gitamedia.

Harmer, Jeremy. 1986. Teaching and Learning Grammar. London: Longman Inc. . 1991. Making sentences. New York: Longman Publishing. 1991. The Pracatice of English Language Teaching. New York: Longman Publishing.

Hornby, A S.1995. Oxford Advance Learner's Dictionary. New York: Oxford University Press.

Huda, Nuril. 1986. The Mastery on English Parts of Speech. Surabaya

Izzan, Ahmad.2008. Basic English Grammar. Jakarta: Kesaint Blanc.

Jupp, T. C. 1968. English Sentence Structure. London: Heinemann Educational Book Ltd.

Langen, John. 2003.English Sentence Structure. Boston: McGraw Hill.

Murphy, Raymond. 2001. English Grammar in Use. Cambridge: Cambridge University Press.

Nurmayani. 2011. Improving The Students' Grammar Through STAD Technique.(Unpublished)

Rozakis, Laurie. 2003. English Grammar for Utterly Confused. New York: Mc Graw Hill.

Schrampfer Azar, Betty. 1992. Fundamental of English Grammar. New Jersey: Prentice Hall. 
. 1999. Understanding and using English Grammar. USA:

Longman Inc.

Scott.1976.English Grammar. London: ELBS and Heinemann Education Book.

Shobirin, R.Maas. 2008. Basic English Grammar. Jakarta: PT. Tangga Pustaka.

Swan. 1988. Grammar Rules. Cambridge: University press.

Thomson and Martinet. 1995. A Practical English Grammar. London: Oxford University Press.

Tyler, Ralph.W. 1949. Basic Principles of Curriculum and Instruction. Chicago: The University of Chicago Press.

Warriners Wishon and Burks.1980. Let's Write in English. New York: American Book Company 